\title{
Trajectory of European Integration and Lessons for Regional Cooperation in East Asia:
}

The Costs of Success

Jinwoo Choi

(Hanyang University)

\section{$\langle$ Contents >}

I . Introduction

II Theories of International Relations and Integration in East Asia
III. What Europe Means for East Asia

IV. Conclusion

- Keywords: regional integration, integration theory, European Union, distributional problems, democratic deficit, East Asian integration.

\section{【 ABSTRACT 】}

While comparison of initial conditions for institution-building in Europe and Asia would lead us to a pessimistic and defeatist view with regard to the prospect for economic integration in East Asia, the move to integration in this region is now gaining momentum any way. The driving force of regional cooperation in East Asia may come from sources that are different from the European case. Once integration process starts up, however, it is possible that the process resembles the European experience more and more, because it is the logic of market that works at the core.

Drawing on the analysis of Europe's experience, this paper focuses on possible problems that could arise as a result of economic integration in East Asia. As integration of economies of East Asia proceeds, The market force unleashed in the process will propel economic growth in this region, but it will also possibly worsen inequality problem as well Such market failures could in turn engender strong anti-integration sentiments in quarters of participating countries that question the legitimacy of the whole integration project, throwing all enterprise of economic integration into disarray. Such negative sentiments also can be mobilized for electoral purposes, further making it hard to sustain cooperative framework among states. The point here is that Europe shows the significance of being attentive to the consequences of economic integration: distributional problems and resulting erosion of legitimacy. In this regard, Europe's experience is valuable for East Asia in delineating a roadmap for future steps toward regional integration.

* This work was supported by the research fund of Hanyang University (HY-2000-G). 


\section{Introduction}

Regional trade agreements are in vogue around the world. According to an OECD report published in 2000, 119 regional trade arrangements are in force as of 1999. Since the creation of the WTO in 1995, 80 regional trade agreements covering trade in goods and services have been reported.1)

Europe has been the forerunner in this movement of regional integration since the creation of ECSC (European Coal and Steel Community) in 1952 and the establishment of EEC (European Economic Community) in 1957. Following these new European enterprises ensued the first wave of integration in the 1950s and 1960s. Renaissance in European integration in the 1980s again has stimulated in two ways countries in other parts of the globe to reinvigorate their attempts for regional integration: First, Europe's success story shows the possibility that regional integration can be a very effective growth strategy; second, European integration and its spillover effect into other regions awakened many formerly unorganized countries to the risk of becoming victims of negative externalities in the form of 'trade diversion effect,' which results from being alienated from regional trade arrangements.

However, East Asian countries have long remained as exceptions to these global trends. Until recently, the Republic of Korea, Japan, Hong Kong, China and Mongolia were listed as the only countries that were not included in any preferential trading relations.2) To be sure, it would be unfair to say that actions for regional cooperation had been completely lacking in East Asia. Nevertheless, past initiatives did not go far enough to bring about any meaningful changes in the trading arrangements among countries in this region.

Why had there not been fruitful attempts for regional integration in East Asia for so long, while other regions such as Europe and North America have accumulated impressive achievement in building up integrated economies? There exists an array of diagnoses imbued with pessimism with regard to the factors for underdevelopment of regional integration in East Asia. The identified causes include: too much hegemonic power, ${ }^{3)}$ instability in distribution of power, ${ }^{4)}$ diversity of the region,5) reluctance to institutionalization, ${ }^{6)}$ unresolved tension stemming from the historical memory, ${ }^{7)}$ the mode

1) OECD (Organization for Economic Cooperation and Development), The European Union's Trade Policies and Their Economic Effects (Paris: OECD, 2002), pp. 23-24.

2) OECD (2002), p. 24.

3) Donald Crone, "Does Hegemony Matter? The Reorganization of the Pacific Political Economy," World Politics vol. 45, no. 4 (1993).

4) Joseph M. Grieco,. "Systemic Sources of Variation in Regional Institutionalization in Western Europe, East Asia, and the Americas," in Edward D. Mansfield and Helen V. Milner, eds, The Political Economy of Regionalism (New York: Columbia University Press, 1997).

5) Rosemary Foot, "Regionalism in Pacific Asia," in Louise Fawcett and Andrew Hurrell, eds., Regionalism in World Politics: Regional Organization and International Order (Oxford: Oxford University Press, 1995). 
of transnational economic activities, ${ }^{8)}$ etc. From these perspectives, East Asia is so different from Europe that there are not much to learn from European experiences.

And yet, what is happening in East Asia these days defies such pessimistic accounts. Long been lackluster in envisaging, let alone developing, formal arrangement for economic cooperation among countries in the region, East Asia now suddenly appears to appreciate the virtue of regional integration and the peril of going alone. So they gather in Bangkok in early October 2003 and discuss the roadmap for strengthening ties among ASEAN +3 countries especially in economic area. And the trend was reinforced in APEC summit in Bangkok later in the month. Besides, a flurry of academic research and government reports authored by scholars and government officials in East Asian countries point to the desirability and necessity of bilateral or mini-lateral free trade agreements. Encouraged and urged by those studies and reports, governments of East Asian countries are shopping around for their trade agreement partners within East Asia and in other areas. A series of free trade agreements were either signed, or in the process of negotiation, or in the stage of feasibility test among Korea, Japan, China and the ASEAN. Korea has finally ratified an FTA (Free Trade Agreement) with Chile in early 2004, and has agreed with Japan and Singapore respectively to conduct a research for the desirability and feasibility of an FTA. Japan is also in the process of negotiating a bilateral FTA with Singapore and Mexico.

The reasons for the surge of interests in economic integration among East Asian countries are many. Above all, it fits commercial intetests. A free trade area promotes trade among countries, and it accompanies economic growth. Second, regional integration in other regions stimulates East Asian countries. It brings up the notion that FTA is an effective tool and an inevitable option for surviving and prospering in this competitive world, and that the negative externality of other regional groupings might adversely affect their economies.9) Third, as the process of globalization spreads, opportunities to contact foreign people and new cultures either through media or direct contacts with foreigners dramatically increase. As a result, familiarity with foreigners, new mode of thinking, and new life style also has been enhanced, so that historical animosity among neighboring countries and ethnocentric sentiment becomes significantly diluted.

Recent efforts to step up economic integration, however, does not mean that East Asia has successfully overcome or bypassed all the constraints and obstacles that hitherto hindered attempts for economic integration. Quite contrary, although East Asia may have been able to remove some hurdles in the initial stage, it will certainly have to face

6) Miles Kahler, "Institution-Building in the Pacific," in Andrew Mack and John Ravenhill, eds., Pacific Cooperation: Building Economic and Security Regimes in the Asia-Pacific Region (Boulder: Westview, 1995).

7) Foot (1995).

8) Walter Mattli, The Logic of Regional Integration: Europe and Beyond (Cambridge: Cambridge University Press, 1999), pp. 174-178.

9) Mattli (1999), p. 166. 
further difficulties.

In this paper, a detailed analysis of expected economic gains of regional integration and their political and social effects is not pursued, because such studies have been exhaustively done by many economists and political scientists elsewhere. Instead, drawing on Europe's experience, I will focus on possible problems that could arise as a result of economic integration in East Asia. Before turning to Europe's lessons, theoretical accounts for the hitherto sluggish pace of regional integration in East Asia are presented with critical remarks on them first. Then I will proceed to discuss what European experiences tell us. I will conclude with the comment on why Europe's experience is valuable for East Asia.

\section{Theories of International Relations and Integration in East Asia}

\section{Realism}

From the realist point of view, conditions for regional integration in East is wanting. The power-centered view of realist accounts suggests at least five factors that are likely to bear on the emergence and sustenance of regionalism: relative gains problem, alliance politics, magnitude of hegemony, changes in relative disparity, and existence of common external threats. First, if states are accorded asymmetric distribution of gains from cooperative exchanges among states, states benefiting less than others will have a lower incentive to join regional agreements designed to promote economic cooperation. Second, states tend to trade more freely with partners that are less threatening to their security, because states are naturally concerned with the possibility that gains accrued to adversarial trade partners could be used to beef up their military capabilities. Therefore, regional integration would be easier among allies. Third, a willing hegemon greatly enhances the likelihood of institutionalized cooperation among states, according to hegemonic stability theories. But not always, says Crone. He questions the linear relationship between hegemonic power and institutionalization of international order. His comparative study of Europe and Asia demonstrates that not only too little hegemony, but also too much hegemony works as an adverse condition for regime formation. Fourth, changes in relative disparity among states are also important. According to Grieco, "the level of institutionalization of international cooperation varies depending on the amount of change taking place in the relative capabilities of partners." 10 ) If relative disparity shifts rapidly, the likelihood of institutionalization is low. Where relative position among states is stable over time, institutionalizing is more likely. Fifth, as the European experience demonstrates, a high level of common military threat from outside enhances the likelihood of emergence of multilateral institutions.

10) Grieco (1997), p. 176. 
For East Asia, all these factors identified by realism pose grave challenges. First, in East Asia, suspicion among states still runs high. In East Asia, many countries are suspicious of Japanese intention and Chinese ambition, due to the historical memory of colonialism and imperial China. Japan and China also consider each other more as an archrival than as a trustworthy partner in the realm of security. Japan's failure to convince other East Asian countries that Japan as a "normal state" would not repeat its prewar and wartime orientation in which it tried to impose its idea of the Great East Asian Co-prosperity Zone on other countries. China's growing power in economic and military area also does not relieve the concerns of other countries. Rather, it causes the anxiety for neighboring countries about a hegemonic China. Among neighbors suspicious of each other, the relative gains problem is brought into relief. States are more wary of changes in power disparity among competitors than allies. Therefore, the configuration of power politics in East Asia is not conducive at all to regional integration.

Second, the politics of hegemonic stability in East Asia also augur ill for regional integration. As many observers point out, the non-communist Asia during the Cold War is characterized by the 'hub-and-spokes' bilateralism between the US and Asian countries, where the asymmetry of power distribution was extreme. While the lack of hegemonic power is also antithetical to regime formation, the predominance of the US power has deterred, rather than facilitated, institutionalization of interstate relations in East Asia. Extreme hegemony of the US "inhibits regime formation by shaping the incentives of both superordinate and subordinate actors away from joint solutions." In East Asia, because of hegemony "a fragmented, bilateral system of relations, rather than multilateral regimes, was formed". 11) Moreover, the status of the US as a lone superpower in the post-Cold War world and its even upgraded relative power position resulting from decade-long robust economic growth during the 1990s that outpaced the growth rate of all other industrial powers are not expected from this viewpoint to affect the prospect of regime formation positively in East Asia.

Third, Grieco hypothesizes that "when the relative disparities in capabilities within a region are shifting over time, disadvantaged states will become less attracted to institutionalization and the latter will become less likely to occur."12) That is, institutionalization is more likely when the distribution of power is stable than when the distribution of power is changing. Grieco says:

if less powerful countries in a region have experienced or are experiencing a significant deterioration in their relative capabilities then they might be concerned that the enhancement of regional economic ties brought about by institutionalization could accentuate regional imbalances in capabilities even further in favor of the relatively stronger partners. From the viewpoint of the less powerful regional states, closer institutional ties and the thickening web of economic transactions they facilitate and

11) Crone (1993), p. 504.

12) Grieco (1997), p. 176. 
foster might thereby yield a more domineering partner in the future. Concerned in this way about trends in relative capabilities and potential bargaining power, the relatively weaker partners might shy away from institutionalization of regional relationships with stronger partners in the area. ${ }^{13)}$

From this perspective, the surge of Chinese power in recent years, be it economic, military, or both, does not bode well for regional cooperation. Wary of a fundamental change in the power configuration in East Asia caused by China's rise, lesser powers in East Asia would tend to shrink from institutionalization.

Fourth, no common threat perception has existed in East Asia since 1945.14) Sharing an external enemy could lead countries to cooperate each other, because common security concerns iron out the differences among the countries more easily in issue areas of less significance. But East Asian countries have not had common external threats as Europe had in the formative years of European integration during the early Cold War period. It means countries in East Asia simply do not share common security interests. As a matter of fact, they rather regard each other as security threats, as shown in the rivalry between Japan and China. The lack of common threat perception among East Asian countries results in the underdevelopment of international institutions in this region.

In short, from the power-centered view of realism, prospects for regional trading arrangements should remain bleak. Nevertheless, as mentioned above, the wave of regionalism seems to reach East Asia finally. Realism may be able to provide plausible accounts for the long period of under-institutionalization, but it does not seem to fit the recent trends in East Asia.

\section{Neo-functionalism}

Neo-functionalism provides another explanation for European success and East Asian failure in regional integration. Neofunctionalism, rooted in the liberalist tradition of theorizing international relations, starts from the recognition of the significance of interdependence, not only between states, but also between areas of human activity. The main thrust of neo-functionalism is its emphasis on the logic of the spillover effect and the role of transnational actors and supranational authority.

First, the spillover effect reflects the expansive logic of integration. This logic is set in motion as it is recognized that policies made pursuant to an initial task and grant of power can be made real only if the task itself is expanded. ${ }^{15}$ )

The spillover process can be divided into two parts: economic and political. Economic spillover relates to the process of further incorporation of various areas of economic

13) Grieco (1997), p. 176.

14) Foot (1995), 229-30.

15) David Mutimer, "1992 and the Political Integration of Europe: Neofunctionalism Reconsidered," Journal of European Integration (Revue d'Intégration Européenne) vol. 13, no. 1, 1989, p. 79. 
activity that have initially remained outside the integration framework. Political spillover relates to the political effect of economic integration, leading to incorporation of politically sensitive issue areas which have been untouched in the initial integration project. From the neo-functionalist view, political spillover is likely to take place as integration in economic sphere proceeds because politics and economics are not separate spheres of social life, but are intimately and inextricably intertwined. ${ }^{16)}$ Therefore, what has started as a somewhat modest economic integration project, once launched could ultimately lead to political integration, the point at which most functions normally performed by national governments were transferred to international authorities. ${ }^{17)}$ Even if the integration process has been launched purely as an economic growth project based on laissez faire ideology, the need for political integration will emerge because of their interdependence.

Second, the integration process promotes, and is nurtured by, the emergence of interest groups, notably industrial groups-business and labor-which tend to unite beyond their former national confines in an effort to make common policy and obtain common benefits (Haas 1958, p. xiii).18) Even interest groups organized within national boundaries including firms and local governments will become keen to the effects that Euro-policies have on them and will try to find ways to turn the Euro-policy making process to their advantage. In this regard, integration process contributes to the proliferation of transnational actors. In other words, integration is accompanied by the Europeanization of the scope of interest group activity.

The movement toward further integration also entails a greater role for supranational authority. The integration process creates, and is facilitated by, supranational bureaucrats who can, and do, deliberately engineer links among tasks and sectors in efforts to enhance their own authority and to push toward the complete political unification of countries to which they are committed. 19) The creation of more powerful EC institutions in turn promotes the sense that national governments are not the only places to find solutions to distributional conflicts. The extended scope of policy competency and the enhanced institutional power given by institutional reform packages such as the SEA and the Maastricht treaty would endow the EC institutions with the capability to mobilize fresh demands and supports from transnational actors for enacting further integrationist policies.

From this perspective, the process of European integration is the process in which

16) Mutimer (1989), pp. 75-76.

17) Donald J. Puchala, "The Integration Theorists and the Study of International Relations," in Charles Kegley and Eugene Wittkopf, eds., The Global Agenda, 2nd ed. (New York: Random House, 1988), p. 204.

18) This vision of integration, as Streeck and Schmitter point out, in many ways bears "strong resemblance to a model of interest politics that....came to be known.....as neocorporatism" (Streeck and Schmitter 1991, p. 135).

19) Puchala (1988), p. 205. 
spillover pressure is borne out by newly empowered supranational actors and transnational actors awakened to the benefit of integration. Important factors for the progress in integration are, therefore, whether there exists functional linkage between policy areas and whether supranational and transnational actors have enough ability and incentives to expand the scope of integration into new areas.

For these dynamics to come into force, background conditions for initial institution-building should exist: "pluralistic social structures, substantial economic and industrial development, and common ideological patterns among participating units."20) Europe seems to have had all these. While it is hard to say that West European countries were more or less homogenous in their politics and economy, they all shared the traits of advanced capitalist democracy. They also have religious commonality: belief in Christianity.

Unlike Europe, East Asia does not enjoy such fortune. East Asian countries could not be more diverse in the level of economic development, political system, and religious orientation. Some are rich, but some are very poor. Japan is a member of G-7, for example, while some countries in this region are ridden with extreme poverty. In political aspect, democratic countries such as Korea, Japan, and Thailand coexist with socialist countries like China and Vietnam, and such authoritarian states as Myanmar. While Confucian influence remains strong in some parts of the region, there are others where Buddhism, Catholicism, or Islamism dominates religious life of their people.

In sum, no optimistic prospects for regional integration in East Asia can be expected from the neofunctionalist view.

\section{Culturalism}

The pessimistic accounts by realism and neofunctionalism of East Asia's prospect for economic integration resonate in the culturalist perspective as well. Institutional underdevelopment in East Asia is often attributed to the cultural traits of the countries in this region. Contrary to the Westerners who are said to tend to "define relationships in legally binding form, thus giving them a fixed and enforceable character," Asians are known to prefer "the loosest possible form of relationship in order to secure the maximum amount of room for maneuver." 21 ) Reluctance of Asians toward institutionalization of inter-state relations, it is said, stems from such cultural backgrounds. In addition, for the people of ASEAN countries, many of who still have vivid memories of sufferings imposed upon them by European powers during the colonial period, institutional formalism is identified with Western values so that it could well conjure up emotional resistance to international institutionalization in general. In this regard, it may not be an accident that Thailand, the country never subsumed under a colonial power, is most eager

20) Ben Rosamond, Theories of European Integration (London: St. Martin's, 2000), p. 69.

21) Hadi Soesastro and Simon Nuttall, "The Institutional Dimension," a paper presented at the Council for Asia-Europe Cooperation, Tokyo, November 4-5, 1997. 
and active in accommodating international organization among Southeast Asian nations. Therefore, cultural dimension also works against regional integration in East Asia.

\section{What Europe Means for East Asia}

Then, the question is, what makes East Asia geared for FTAs? Is that because the conditions that have impeded the creation of preferential trade zone in this region are changing? Or, are there any new developments that force or entice East Asian countries to pursue tightened cooperative framework in the area of commerce, while the existing conditions are unchanged? And even if countries in East Asia are more groping for regional integration now than before, are there not going to be any new obstacles that hinder the enterprise? What should East Asian countries prepared for? It seems that it is in this regard where European experiences provides fertile ground for investigating a roadmap for East Asia.

Europe means several things for East Asia. First of all, Europe is an entity to deal with, whether as a competitor or as a partner for cooperation. Europe is a major trading partner of East Asian countries, and its importance is growing. It is also a destination of foreign direct investment and portfolio investment by East Asians. Money flows the other way around as well, so Europe is also an origin of investment money that goes to East Asia. In some international organization such as the World Trade Organization, European Union acts as one entity. As such, Europe is both a challenge and an opportunity. The spread of integration movement around the world attests to it. An ever more tightly integrated Europe in the 1980s and 1990s spawned sense of urgency among countries in other continents that they lagged behind a bigger and stronger Europe. Such fear was a driving force of integration in other parts of the world. Integrated Europe can be a bigger market for East Asia on the one hand, but its enhanced market power carries a bigger leverage in international negotiation.

Secondly, Europe is an example to be modeled after. Europe boasts politically stable democracy, prosperous economy, and attractive and stimulating cultural heritage. Above all, its experiment of regional integration was, and still is, a tremendous success. It brought about peace and prosperity on the European continent. It also consolidated democracy in countries where political system was fragile and capitalism was feeble. As such, Europe provides a rationale for East Asia to pursue regional integration as a way to stabilize political situation and to improve economic conditions. Further, it could show a strategic roadmap for the economic integration in East Asia. Europe's goal was ambitious from the beginning, but its approach has been practical all along, adjusting flexibly to changes in international environments and the needs of the member states and peoples. Steps taken were modest and gradual most of the time, but steady accumulation of them for fifty years yields the most extraordinary phenomenon in the history of international relations: voluntary and substantial transfer of sovereignty by nation-states to 
supranational authority.

Thirdly, Europe also shows East Asia what to beware of. The process of European integration was far from smooth, as illustrated in the EPC/EDC fiasco in 1954 and the empty chair crisis in 1965 . European integration also stagnated during the 1970 s when member states failed to forge a community-level solution and tried to cope with worldwide economic downturn in a fragmented way. In the past, the fault line that caused such troubles was usually drawn between nationalism and supranationalism. While tension between these two forces still hovers, new challenges arise from the very success of Europe's market-oriented economic integration: distributional problems and democratic deficit. It is these aspects that I will turn to from here on.

As theories of international relations point out, neither system-level factors nor unit-level conditions are favorable to economic integration in East Asia. Non-existence of security community among countries and a strong US presence in the region renders the task of economic integration quite demanding. Heterogeneity of constituent countries in political, economic, and cultural terms will make it even more daunting. Compared to Europe, East Asia definitely has tougher obstacles to overcome. Tough as it may be, regional integration should not be an impossible enterprise in East Asia, if new circumstances arise and incentive structure of East Asian countries change, and if a strategy for economic integration is drawn carefully enough. However, even if East Asia passes both system-level and unit-level tests and succeeds in building a preferential trading arrangement thanks to circumstantial changes, the European experience leads us to anticipate that East Asia will have to encounter more challenges that include the two problems that I mentioned above.

\section{Distributional Problems}

After a long period of "Eurosclerosis" and "Europessimism" in much of the 1970s and the early 1980s, which coincided with the "dark age" of the European Community (now the European Union), Europe has relaunched an ambitious economic growth project, culminating in the Single European Act (hereafter the SEA) and the 1992 project, thus spawning a sense of "Euro-optimism." It has been emphatically and repeatedly pointed out that the fully developed internal market of the European Community would bring aggregate benefits to EU as a whole, to a level that is unattainable without integrationhence so much talk of the "cost of non-Europe."22)

Accompanying this elevated hope was the concerns about the distributional consequences of a fully integrated and barrier-free internal market in which capital, services, goods and people can freely move. The worry has been voiced that the

22) Paolo Cecchini, 1992: The European Challenge--The Benefits of a Single Market (Aldershot, UK: Wildwood House, 1988). Indeed, it has been suggested that the European countries would not sustain their relative status in the world political economy if combined efforts to reassert themselves were absent. 
implementation of the 1992 project in the newly emerging "frontier-free Europe" would produce both winners and losers, at least in the short nun. Faced with the possibility of uneven distributional consequences, EU has attempted to develop various policy measures to cope with the problem. Two of them deserve special attention: regional policy for reducing disparities between regions, and social policy to close gaps between classes.

It has been widely acknowledged that the integration of the European Market can lead to either of the following two directions. On the one hand, the increased mobility of capital in the internal market of the EC might result in further concentration of industrial investment in the already highly industrialized regions. Since these regions have sophisticated infrastructures and well-trained labor forces, and are hence able to command higher productivity, it is possible that investment capital is attracted to the fertile resources for industrial activities these regions offer. This is what Streeck calls "the agglomeration effect."23) If it occurs, then more industrialized countries will benefit from it while the relatively poor, less industrialized countries will suffer, and already impoverished regions will get even poorer.

On the other hand, unrestrained capital movement also might result in the flight of capital from the core to the periphery. While lacking the developed infrastructure and skilled labor compared to the core countries, the peripheral countries do have their own competitive edge in luring firms: the lower wage level. Seeking more cost-efficient methods of business operation, investors might be tempted to escape from the high wage regimes of the core and move to the periphery. This is what can be called "Delawarization" or the "Sunbelt effect." If it happens, the result will be the growth of industry in the periphery and its decline in the core, and workers in the core countries will end up either losing their jobs or earning lower wages and working under worse working conditions.

Regional policy and social policy were the EU's response to these concerns. To be sure, what EU is doing may not be enough. EU budget allocated to close the gap between rich and poor regions-structural funds-is considered too small to remedy the existing disparities. The problem of regional disparities will further widen after the EU's eastward Expansion in 2004, but EU does not seem to have sufficient resource to deal with the problem.

As to the EU's effort to protect labor's interests, even more criticism could be raised. A series of social legislation by EU has been characterized as "no more than a statement

23) Wolfgang Streeck, "More Uncertainties: German Unions Facing 1992," Industrial Relations vol. 30 , no. 3, 1991. This is also called 'backwash effect.' According to Leonardi, backwash effects entails the attraction of capital, skilled labor, entrepreneurship, technology, etc. towards core areas and discouragement of the movement of production factors from the developed core to the less developed periphery. Leonardi further notes that this notion provides the major theoretical argument that has been used in the development of regional policy in the EC. See Robert Leonardi, Cohesion in the European Community: Illusion or Reality? "West European Politics" vol. 16 , no. 4 , 1993 , pp. 496-497. 
of principles"24) or even as "non-binding and heavily diluted declaration of principles."25) As such, EU social policy has been declared to be "a major defeat for European labor and an obstacle rather than an aid to the development of the social dimension."26)

Nevertheless, what is important about EU for East Asia on this matter is that EU is taking these distributional problems seriously, and trying to find measures to cope with them. As a matter of fact, legislation of regional policy and social policy at EU level is not an easy task. First, to aid backward regions, EU needs to raise money first. But EU is already spending more than a third of its total budget for structural funds, 27$)$ and EU budget is constrained by EU law not to exceed $1.27 \%$ of total GNP, as of 1999.28) With this ceiling on budget in place, EU does not have much room for the increase of the amount allocated to regional policy.

Second, as to social policy, harmonization in this area is extremely difficult, because each member state has long developed their own social system that has been tailored to the changing needs of people and the state for long time. National social system also has developed vested interests, and these vested interests often are keen to preserve the current system. Any attempt for a European social system, therefore, is an anathema to these vested interests, and will face serious resistance from citizens of member states.

Given these limits placed on the EU-level legislation in regional and social policy, it would be too much to expect EU to develop an effective mechanism for dealing with distributional consequences of market integration. Maybe what EU is doing cannot be solutions to the problems, but at least it succeeds in addressing the problem and in setting the agenda. By doing so, it summons support for further integration from trade unions and regional political bodies.

\section{Legitimacy Problems}

In the Treaty on European Union, EU member states stipulate that they are attached to "the principle of liberty, democracy and respect for human rights and fundamental freedoms and of the rule of law." While all member states of EU are undoubtedly well-developed democratic political systems, however, EU is being criticized for not

24) David Coombes and Nicholas Rees. "Regional and Social Policy," in Leon Hurwitz and Christian Lequesne, eds., The State of the European Community: Policies, Institutions \& Debates in the Transition Years (Longman, UK: Lynne Rienner Publishers, 1991), p. 217.

25) Rhodes, Martin. "The Social Dimension of the Single European Market: National versus Transnational Regulation," European Journal of Political Research, vol. 19, 1991, p. 246.

26) Peter Lange, "The Politics of Social Dimension," in Alberta M. Sbragia, ed., Europolitics: Institutions and Policymaking in the "New" European Community (Washington, DC: The Brookings Institution, 1992), p. 12.

27) About half of EU's total budget goes to CAP (Common Agricultural Policy). The share of CAP is declining steadily.

28) lain Begg and Negel Grimwade, Paying for Europe (Sheffield: Sheffield Academic Press, 1998), p. 68 . 
being democratic enough. The debate on 'democratic deficit' illustrates the point. The outcry is that while a growing number of policy areas are falling under the purview of European Union and an increasing number of decisions are made at supranational level, no concomitant development of democratic mechanism is accompanied to ensure adequate level of public participation in EU affairs, accountability of decision-makers, and transparency of decision making process. Such problems stem from many sources: qualified majority voting in the Council of Ministers; direct effects of EU law; and secrecy of Council and Commission meeting, ${ }^{29)}$

The efforts to remedy the problem of democratic deficit come from two directions. One is the effort to strengthen the power and authority of the European Parliament, and the other is the attempt to apply the principle of subsidiarity to EU decision-making. They represent, respectively, supranational and national solutions. It remains to be seen how effective these measures are in improving the democratic practice in EU. Current situation does not seem to allow us an optimistic expectation. One of prominent problems is the low turnout in the election for European Parliament. The turnout has progressively declined since the introduction of popular vote in 1979.30) The low turnout in European election and the resulting lack of legitimacy of the European Parliament as a representative body of Europeans indeed bode ill for democracy in EU and its legitimacy. However, again, what attracts attention here is that the problem of democratic deficit was recognized to be a serious impediment on the way to further integration and concrete measures are put in practice to correct the situation.

\section{Conclusion}

What can we learn from the experience of European integration? Comparison of initial conditions for institution-building in Europe and Asia is more likely to lead us to a pessimistic and defeatist view with regard to the prospect for economic integration in East Asia, than to drive us to find a useful roadmap for future steps toward regional integration. The move to integration is now gaining momentum any way. The driving force may come from sources that are different from the Europe's case. Indeed, neofunctionalists admit, "it was also possible that locally specific conditions (or 'functional equivalents' to the background conditions in Western Europe) might be sufficient for the generation of integrative potential in other regions."31) Once integration

29) Lisa Martin, "International and Domestic Institutions in the EMU Process," Economics and Politics vol. 5, no. 2, 1993.

30) Julie Smith, Europe's Elected Parliament (Sheffield: Sheffield Academic Press, 1999), p. 111.

31) Rosamond (2000), p. 70. This is basically to say that there exist regionally specific background conditions for economic integration. If so, then neofunctionalism may have to give up being a general theory of regional integration, as far as the initial stage of regional integration is concemed. In this sense, neofunctionalism should be regarded not as a theory about how regional 
process starts up, however, it is possible that the process resembles European experience more and more, because it is the logic of market that works at the core. That is, once economies of East Asia are integrated, the market force unleashed by integration will propel economic growth in this region but it will also possibly worsen inequality problem as well. Such market failures could in turn engender strong anti-integration sentiments in quarters of participating countries that question the legitimacy of the whole integration project, throwing all enterprise of economic integration into disarray. Such negative sentiments also can be mobilized for electoral purposes, further making it hard to sustain cooperative framework among states. The point here is that, Europe shows the significance of being attentive to the consequences of economic integration: distributional problems and resulting erosion of legitimacy. 


\section{References}

Begg Iain and Negel Grimwade. 1998. Paying for Europe. Sheffield: Sheffield Academic Press.

Cecchini, Paolo. 1988. 1992: The European Challenge--The Benefits of a Single Market. Aldershot, UK: Wildwood House.

Coombes, David and Nicholas Rees. 1991. "Regional and Social Policy." In Leon Hurwitz and Christian Lequesne, eds. The State of the European Community: Policies, Institutions \& Debates in the Transition Years. Longman, UK: Lynne Rienner Publishers.

Crone, Donald. 1993. "Does Hegemony Matter? The Reorganization of the Pacific Political Economy." World Politics vol. 45, no. 4, pp. 501-525.

Foot, Rosemary. 1995. "Regionalism in Pacific Asia." In Louise Fawcett and Andrew Hurrell, eds. Regionalism in World Politics: Regional Organization and International Order. Oxford: Oxford University Press.

Grieco, Joseph M. 1997. "Systemic Sources of Variation in Regional Institutionalization in Western Europe, East Asia, and the Americas." In Edward D. Mansfield and Helen V. Milner, eds. The Political Economy of Regionalism. New York: Columbia University Press.

Haas, Ernst B. 1958. The Uniting of Europe: Political, Social, and Economic Forces, 1950-1957. Stanford: Stanford University Press.

Kahler, Miles. 1995. "Institution-Building in the Pacific." In Andrew Mack and John Ravenhill, eds. Pacific Cooperation: Building Economic and Security Regimes in the Asia-Pacific Region. Boulder: Westview.

Lange, Peter. 1992. "The Politics of Social Dimension." In Alberta M. Sbragia, ed. Europolitics: Institutions and Policymaking in the "New" European Community. Washington, DC: The Brookings Institution.

Leonardi, Robert. 1993. "Cohesion in the European Community: Illusion or Reality?" West European Politics, vol. 16, vo. 4, pp. 494-517.

Mansfield, Edward D. and Helen V. Milner. 1997. "The Political Economy of Regionalism: An Overview." In Edward D. Mansfield and Helen V. Milner, eds. The Political Economy of Regionalism. New York: Columbia University Press.

Martin, Lisa. 1993. "International and Domestic Institutions in the EMU Process." Economics and Politics vol. 5, no. 2, pp. 125-144.

Mattli, Walter. 1999. The Logic of Regional Integration: Europe and Beyond. Cambridge: Cambridge University Press.

Mutimer, David. 1989. "1992 and the Political Integration of Europe: Neofunctionalism Reconsidered." Journal of European Integration (Revue d'Intégration Européenne) vol. 13, no. 1, pp. 75-101.

OECD (Organization for Economic Cooperation and Development). 2000. The European 
Unions Trade Policies and Their Economic Effects. Paris: OECD.

Puchala, Donald J. 1988. "The Integration Theorists and the Study of International Relations." In Charles Kegley and Eugene Wittkopf, eds. The Global Agenda, 2nd ed. New York: Random House.

Rhodes, Martin. 1991. "The Social Dimension of the Single European Market: National versus Transnational Regulation," European Journal of Political Research, Vol. 19, pp. 245-280.

Rosamond, Ben. 2000. Theories of European Integration. London: St. Martin's.

Smith, Julie. 1999. Europe's Elected Parliament. Sheffield: Sheffield Academic Press. Soesastro, Hadi and Simon Nuttall. 1997. "The Institutional Dimension." A paper presented at the Council for Asia-Europe Cooperation, Tokyo, November 4-5.

Streeck, Wolfgang. 1991. "More Uncertainties: German Unions Facing 1992." Industrial Relations vol. 30, no. 3, pp. 317-349.

Streeck, Wolfgang and Philippe C. Schmitter. 1991. "From National Corporatism to Transnational Pluralism: Organized Interests in the Single European Market," Politics \& Society, vol. 19, no. 2, 1991. 